OPEN ACCESS

Edited by:

Quancai Sun,

Jiangsu University, China

Reviewed by:

Shiming $L i$

The State University of New Jersey,

United States

Qingying Zhang,

Peking University Health Science

Centre, China

${ }^{*}$ Correspondence:

Pin LV

Ivpin@hebmu.edu.cn

Yan Zhang

snowwinglv@126.com

tThese authors have contributed equally to this work

Specialty section: This article was submitted to Nutrition and Food Science

Technology,

a section of the journa

Frontiers in Nutrition

Received: 15 October 2021 Accepted: 16 November 2021 Published: 23 December 2021

Citation: Huang $Y$, Cui L, Yang $H$, Chen $N$, Guo H, Gan X, Wang R, Shi W, Wu Y,

Zhang $Y$ and LV $P$ (2021) Lysozyme

Improves the Inhibitory Effects of

Panax notoginseng Saponins on

Phenotype Transformation of Vascular

Smooth Muscle Cells by Binding to

Ginsenoside Re.

Front. Nutr. 8:795888.

doi: 10.3389/fnut.2021.795888

\section{Lysozyme Improves the Inhibitory Effects of Panax notoginseng Saponins on Phenotype Transformation of Vascular Smooth Muscle Cells by Binding to Ginsenoside Re}

\author{
Yun Huang ${ }^{1,2+}$, Lijian Cui ${ }^{3 \dagger}$, Hongchao Yang $^{2}$, Ning Chen ${ }^{2}$, Huishan Guo ${ }^{2}$, Xiaoruo Gan ${ }^{2}$, \\ Rong Wang ${ }^{2}$, Weiye Shi ${ }^{4}$, Yu Wu ${ }^{2}$, Yan Zhang ${ }^{2,5 *}$ and Pin $L v^{1,2 *}$ \\ ${ }^{1}$ Beijing Advanced Innovation Center for Food Nutrition and Human Health, Beijing Technology and Business University, \\ Beijing, China, ${ }^{2}$ Cardiovascular Medical Science Center, Department of Cell Biology, Hebei Medical University, Shijiazhuang, \\ China, ${ }^{3}$ Experiment Center, Hebei University of Chinese Medicine, Shijiazhuang, China, ${ }^{4}$ College of Food Science and \\ Biology, Hebei University of Science and Technology, Shijiazhuang, China, ${ }^{5}$ Hebei Food Safety Key Laboratory, Hebei Food \\ Inspection and Research Institute, Shijiazhuang, China
}

Panax notoginseng saponins (PNS) have been used to treat cardiovascular diseases for hundreds of years in China. Lysozyme can bind to exogenous compounds and promote their activity. Nevertheless, knowledge of whether there is a synergistic role between lysozyme and PNS is far from sufficient. In this study, we show that the mixture of PNS and lysozyme synergistically inhibited platelet derived growth factor BB (PDGF-BB)-induced vascular smooth muscle cell (VSMC) viability, and in the five main components of PNS, GS-Re, but not GS-Rb1, NG-R1, GS-Rg1, or GS-Rd, reduced VSMC viability by combined application with lysozyme. Next, the supramolecular complexes formed by GS-Re and lysozyme were detected by mass spectrometry, and the binding ability increased with the concentration ratio of GS-Re to lysozyme from 4:1 to 12:1. In the supramolecular complexes, the relative contents of $\alpha$-helix of lysozyme were increased, which was beneficial for stabilizing the structure of lysozyme. The 12:1 mixture of GS-Re and lysozyme (12.8 $\mu \mathrm{mol} / \mathrm{L}$ GS-Re+1.067 $\mu \mathrm{mol} / \mathrm{L}$ lysozyme) repressed PDGF-BB-induced VSMC viability, proliferation, and migration, which were associated with the upregulated differentiated markers and downregulated dedifferentiated markers. Finally, in $\mathrm{CaCl}_{2}$-induced rodent abdominal aortic aneurysm (AAA) models, we found that the 12:1 mixture of GS-Re and lysozyme slowed down AAA progression and reversed phenotype transformation of VSMCs. Thus, Gs-Re combined with a small amount of lysozyme may provide a novel therapeutic strategy for vascular remodeling-associated cardiovascular diseases.

Keywords: Panax notoginseng saponins, lysozyme, Ginsenoside Re, vascular smooth muscle cells, phenotype transformation 


\section{INTRODUCTION}

Vascular smooth muscle cells (VSMCs), a kind of highly differentiated cells in normal vessels, are quiescent and possess a contractile phenotype. As the main component of media, VSMCs not only provide structural support for vessels, but also play a key role in conferring vascular homeostasis. However, VSMCs are not the terminally differentiated cells, and they can shift from the contractile or differentiated to the synthetic or dedifferentiated phenotype in response to various environmental cues, such as growth factor and mechanical stimulation, manifesting themselves as re-entering the cell cycle and migrating from media into the intima $(1,2)$, which are the crucial pathological basis of vascular diseases such as atherosclerosis, hypertension, vascular restenosis, arterial aneurysm and diabetic vascular complications (2-4). Therefore, agents that can effectively inhibit VSMC proliferation and migration may have a crucial role in the prevention and treatment of vascular remodeling diseases.

Sanqi (Sanqi Notoginseng Radix et Rhizoma) comprises the dry root and rhizomes of the plant species, Panax notoginseng (Burk.) F. H. Chen and has been used to treat various cardiovascular and cerebrovascular diseases for hundreds of years in China $(5,6)$. Panax notoginseng saponins (PNS) is the main active component in Sanqi, and according to the pharmacopeia of China, PNS mainly includes Ginsenoside Rb1 (GS-Rb1) (30\%), Ginsenoside Rg1 (GS-Rg1) (25\%), Ginsenoside Rd (GS-Rd) (5\%), Notoginsenoside R1 (NG-R1) (5\%), and Ginsenoside Re (GS-Re) (2.5\%). PNS has numerous pharmacological effects, such as blood dynamics invigoration, cerebral vasodilation, hemostasis, anti-inflammation, antiapoptosis, anti-edema, anti-thromboembolism, anti-coagulation, anti-hyperglycemia, and anti-hyperlipidemia $(7,8)$.

Lysozyme, known as an alkaline enzyme that can hydrolyze mucopolysaccharides in pathogenic bacteria, has a variety of pharmacological effects such as anti-bacterial, anti-fungal, and anti-inflammation (9-11). Coupled with its biocompatibility, non-irritant and non-toxic to tissues, it has been approved as a food additive and is extensively applied in various food substrates (12). Our study and other studies demonstrated that lysozyme could combine with exogenous compounds through producing allosteric regulation (13-15). One molecule of lysozyme can combine with multiple molecules to synthesize supramolecular complexes with different molecular weights. For example, GS$\operatorname{Rg} 1\left(7.88 \times 10^{-5} \mathrm{~mol} / \mathrm{L}\right)$ and GS-Re $\left(6.72 \times 10^{-5} \mathrm{~mol} / \mathrm{L}\right)$ can form 1:1 and 2:1 non-covalent complexes with lysozyme $\left(2.5 \times 10^{-5} \mathrm{~mol} / \mathrm{L}\right)$ under acidic condition, which may have a certain impact on the natural structure and function of lysozyme (16). The decreased stability of natural proteins is shown as the decreased $\alpha$-helix structure and the increased surface hydrophobicity. Lysozyme has three $\alpha$-helix structures, which play key roles in structural stability. Our previous studies found that luteolin and luteoloside influenced the active site of lysozyme in the $\alpha$-helix (15). Moreover, lysozyme promoted the anti-bacterial activity of baicalin, baicalein, and scutellarin and increased the cytotoxicity of caffeine in HepG2 cells (17, 18). It has been previously reported that PNS inhibited VSMC proliferation by blocking the activation of ERK signaling pathway
(19). However, it remains unknown whether lysozyme plays a synergistic role in PNS-repressed VSMC proliferation, and the active ingredients in PNS combined with lysozyme also need to be further investigated.

In the current study, our findings showed that lysozyme promoted the activity of PNS on inhibition of VSMC viability. GS-Re may be the main ingredients of PNS that leads to the decreased VSMC viability through joint application with lysozyme. Next, mass spectral studies show that GSRe and lysozyme could interact with each other and form supramolecular complexes, which significantly increases the contents of lysozyme $\alpha$-helix. Finally, the combined use of GS-Re and lysozyme inhibits the proliferation and migration of VSMCs and ameliorates AAA progression.

\section{MATERIALS AND METHODS VSMC Culture and Treatment}

The mouse VSMC line MOVAS was purchased from ATCC, USA (CRL-2797, USA) and cultured in high-glucose Dulbecco's Modified Eagle Medium (DMEM) containing 10\% fetal bovine serum and $0.2 \mathrm{mg} / \mathrm{ml} \mathrm{G}-418$. VSMCs were pretreated with different concentrations of PNS [Melone Pharmaceutical Co., Ltd., China, dissolved in dimethyl sulfoxide (DMSO)], lysozyme (Melone Pharmaceutical Co., Ltd., dissolved in DMSO), or the mixture of PNS and lysozyme for different time, then stimulated with $10 \mathrm{ng} / \mathrm{mL}$ PDGF-BB (R\&D) for indicated time periods.

\section{Cell Viability Assay}

VSMCs were seeded onto 96-well plates $\left(5 \times 10^{3}\right.$ cells per well) and pretreated with various concentrations of PNS, lysozyme, or the mixture of PNS and lysozyme for different time before stimulation with or without $10 \mathrm{ng} / \mathrm{ml}$ PDGF-BB. Cell viability was measured using cell counting kit-8 (CCK-8 assay; ZOMANBIO, Beijing, China).

\section{Cell Migration Assay}

The migration capability of VSMCs was measured by the woundhealing assay and transwell migration assay.

For the wound-healing assay, directional cell migration of VSMCs was determined in a monolayer using an in vitro scratch wound as previously described (20). After achieving confluence, VSMCs were pretreated with GS-Re, lysozyme, or the mixture of GS-Re and lysozyme for $6 \mathrm{~h}$, and then subjected to injury using $200-\mu \mathrm{l}$ sterilized pipette tips, washed, and stimulated with $10 \mathrm{ng} / \mathrm{ml}$ PDGF-BB for $24 \mathrm{~h}$ or not. Next, VSMCs were fixed with $4 \%$ paraformaldehyde for $30 \mathrm{~min}$ and stained by $0.1 \%$ crystal violet for $10 \mathrm{~min}$. Three different fields of migration were photographed with a microscope (Leica).

The transwell assay was performed using transwell chambers (8- $\mu \mathrm{m}$ pores, Corning Costar). The VSMCs were pretreated with GS-Re, lysozyme, or the mixture of GS-Re and lysozyme for $6 \mathrm{~h}$, then seeded into the upper chamber, and the lower chamber was filled with DMEM containing $10 \mathrm{ng} / \mathrm{ml}$ PDGF-BB or not. Next, VSMCs were allowed to migrate for $10 \mathrm{~h}$, and then fixed with $4 \%$ paraformaldehyde for $30 \mathrm{~min}$. After careful removal of the cells on the upper surface with a cotton swab, the cells adhered to the 
lower surface of the transwell membrane were stained with $0.1 \%$ crystal violet for $10 \mathrm{~min}$. Then, five images of each membrane (the center and four quadrants) were captured under an inverted microscope (Leica) for quantification.

\section{Western Blot Analysis}

Cells were prepared with lysis buffer ( $1 \%$ Triton X$100,150 \mathrm{mM} \mathrm{NaCl}, 10 \mathrm{mM}$ Tris-HCl, pH 7.4, $1 \mathrm{mM}$ ethylenediaminetetraacetic acid, $1 \mathrm{mM}$ egtazic acid, $\mathrm{pH}$ 8.0, $0.2 \mathrm{mM} \mathrm{Na} \mathrm{VO}_{4}, 0.2 \mathrm{mM}$ phenylmethylsulfonyl fluoride, and $0.5 \%$ Nonidet P-40). Equal amounts of protein (60-100 $\mu \mathrm{g})$ were separated by $10 \%$ sodium dodecyl sulfate-polyacrylamide gel electrophoresis and electro-transferred onto a polyvinylidene fluoride membrane. Membranes were blocked with 5\% non-fat milk in tris-buffered saline-Tween for $2 \mathrm{~h}$ at room temperature and incubated with specific primary antibodies against proliferating cell nuclear antigen (PCNA; 1:1,000, ab92552; Abcam, Cambridge, United Kingdom), matrix metallopeptidase 9 (MMP-9; 1:1,000, sc-13520, SantaCruz), SM22 $\alpha$ (1:1,000, ab14106, Abcam), SM- $\alpha$-actin (1:1,000, ab7817; Abcam), or $\alpha$-Tubulin $\left(1: 1,000\right.$, ab7291; Abcam) at $4^{\circ} \mathrm{C}$ overnight. The membranes were then incubated with IRDye $800^{\circledR}$ conjugated secondary antibody (1:20,000, Rockland, USA) for $1 \mathrm{~h}$ at room temperature, following scanning with the Odyssey Infrared Imaging System. The protein bands of interest were quantified using Quantity One software (Bio-Rad, CA, USA).

\section{RNA Isolation and Quantitative Real-Time PCR (qRT-PCR)}

Total RNA was extracted using TRIzol reagent (Invitrogen, MA, USA) and cDNAs were synthesized by reverse transcriptase SuperScript II (Invitrogen). The qRT-PCR was performed using SYBR Green Real-time PCR Master Mix (Invitrogen) and 7300 Real Time PCR System (Applied Biosystems, Carlsbad, CA, USA). For RT-PCR analysis, the following specific primers were used: PCNA forward, 5' -TTTGAGGCACGCCTGATCC- $3^{\prime}$ and reverse, 5'-GGAGACGTGAGACGAGTCCAT-3'; MMP9 forward, 5'-CTAGTGAGAGACTCTACACGGAG-3' and reverse, 5'-GAGCCACGACCATACAGATACTG-3'; SM22 $\alpha$ forward, 5' - GCCCAGACACCGAAGCTA- $3^{\prime}$ and reverse, $5^{\prime}$ - CTGCTGCCATATCCTTACCTT- $3^{\prime}$; SM- $\alpha$-actin forward, $5^{\prime}$-CAGGGAGTAATGGTTGGAATGG- $3^{\prime}$ and reverse, $5^{\prime}$ GCCGTGTTCTATCGGATACTTCAG-3'; $\beta$-actin forward, $5^{\prime}$-TGGAATCCTGTGGCATCCATGAAAC- $3^{\prime}$ and reverse, $5^{\prime}$-TAAAACGCAGCTCAGTAACAGTCCG-3'. The samples were pooled to analyze using the qRT-PCR in triplicate, and averaged by experiment, three times repeatedly $(n=3)$.

\section{Spectral Analysis}

AB SCIEX QTRAP3200 mass spectrometer (American Rockwell Allen-Bradley) was used in mass analysis, set in positive ion mode with the conditions of electrospray ionization mass spectrometry soft enough to study the weak non-covalent interactions. The instrumental parameters were set as follows: detector voltage $3 \mathrm{kV}$, capillary temperature $200^{\circ} \mathrm{C}$, the ionization temperature $300^{\circ} \mathrm{C}$, sheath gas (nitrogen) flow 35 arb, sweep gas (nitrogen) flow10 arb, and scan range $\mathrm{m} / \mathrm{z}$ 200-2,000. Each sample was directly injected via a syringe pump at the rate of $2 \mathrm{ul} / \mathrm{min}$, and the mass spectrum was cumulated for $5 \mathrm{~min}$. Masses were annotated and processed with PeakView. Four milliliter solution of lysozyme [Melone Pharmaceutical Co., Ltd., dissolved in a 5 $\times 10^{-2} \mathrm{~mol} / \mathrm{L}$ Tris- $\mathrm{HCl}$ buffer solution ( $\mathrm{pH} 7.40$ ), containing $5 \times 10^{-2} \mathrm{~mol} / \mathrm{L} \mathrm{NaCl}$ /GS-R (Melone Pharmaceutical Co., Ltd., dissolved in $50 \%$ methanol) at a molar ratio of 1:4 to 1:12 for mass spectroscopic investigation was incubated for $30 \mathrm{~min}$ at $298 \mathrm{~K}$, of which the final concentration was lysozyme $5.0 \times 10^{-5} \mathrm{~mol} / \mathrm{L}$ and saponin from $2 \times 10^{-4}$ to $6 \times 10^{-4} \mathrm{~mol} / \mathrm{L}$. The data were processed in PeakVew 1.2.

By comparing the first-order mass spectra of lysozyme and non-covalent compound, the number of molecules of compound integrated by lysozyme $(N)$ can be calculated to screen out which component was integrated by lysozyme with the highest degree using the following equation:

$$
N=n_{\text {charges }} \times\left(m / z_{\text {complex }}-m / z_{\text {lysozyme }}\right) / M
$$

where $m / z_{\text {complex }}$ and $m / z_{\text {lysozyme }}$ are the ratio of mass to nucleus of non-covalent complex and that of lysozyme, $n_{\text {charges }}$ the number of charges, and $\mathrm{M}$ molecular weight of saponin compound.

Attenuated total reflectance Fourier transform infrared spectroscopy (ATR-FTIR; FTIR-8400s spectrophotometer from Shimadzu Corporation, and horizontal attenuated total reflection accessory from American Perkin Elmer) spectra investigation with the resolution of $4 \mathrm{~cm}^{-1}$ and 60 scans were recorded in the range from 1,000 to $2,000 \mathrm{~cm}^{-1}$. The spectra of Tris- $\mathrm{HCl}$ buffer solution, lysozyme solution $\left(1 \times 10^{-5} \mathrm{~mol} / \mathrm{L}\right)$, GS-Re solution $(1$ $\left.\times 10^{-5} \mathrm{~mol} / \mathrm{L}\right)$, and lysozyme solution $\left(1 \times 10^{-5} \mathrm{~mol} / \mathrm{L}\right)$ with $1 \times$ $10^{-5} \mathrm{~mol} / \mathrm{L}$ GS-Re were collected after the sample compartment was purged with dry air to eliminate the absorption of water vapor. The differential spectrum of pure lysozyme was obtained from the absorbance spectrum of lysozyme solution subtracted by that of Tris-HCl buffer solution, and the spectrum of GS-Re solution was subtracted from that of GS-Re-lysozyme to obtain the lysozyme (after GS-Re was added) differential spectrum. The data were analyzed and graphed in Origin 9.0. The subtractive spectra were subjected to baseline correction within the scope of 1,700-1,600 $\mathrm{cm}^{-1}$ amide I band and smoothed with SavitzkyGolay, then fitted by the Gauss curve fitting with the second derivative and Fourier deconvolution was applied to estimate the position of peaks and half-peak width. The secondary structure contents of lysozyme were calculated according to the absorption bands observed in the amideIregion corresponding to $\alpha$-helix $\left(1,642-1,660 \mathrm{~cm}^{-1}\right), \beta$-sheet $\left(1,613-1,637 \mathrm{~cm}^{-1}\right.$ and 1,682-1,689 $\left.\mathrm{cm}^{-1}\right), \beta$-turn $\left(1,662-1,700 \mathrm{~cm}^{-1}\right)$, and disordered $(1,637-1,645$ $\mathrm{cm}^{-1}$ ) structures $(21)$.

\section{Mouse Model of AAA}

Male C57BL/6J mice, aged 8-12 weeks, were subjected to surgery in accordance with the $\mathrm{CaCl}_{2}$-daubed abdominal aortic aneurysm (AAA) model as previously described (22-24). In brief, the mice were anesthetized and the infrarenal abdominal aortas were surrounded with a small piece of gauze soaked in $\mathrm{CaCl}_{2}(0.5 \mathrm{~mol} / \mathrm{L})$ for $15 \mathrm{~min}$, followed by another piece 
of gauze soaked in saline for $5 \mathrm{~min}$. Mice receiving a single treatment of saline for $15 \mathrm{~min}$ were used as a control group. The mice were sacrificed 21 days later, and the abdominal aorta between the renal arteries and bifurcation of the iliac arteries was isolated from the surrounding retroperitoneal structures. The diameter of the aorta was measured with video microscopy in triplicate midway between the renal artery origin and iliac artery bifurcation. GS-Re $(50 \mathrm{mg} / \mathrm{kg} /$ day) or the mixture of GS-Re and lysozyme $(50 \mathrm{mg} / \mathrm{kg} /$ day, the molar ratio of GS-Re:lysozyme was 12:1) was orally administered by gastric gavage from 7 days before $\mathrm{CaCl}_{2}$ treatment to 21 days after the $\mathrm{CaCl}_{2}$ treatment $(n=8$ per group). All animal procedures conformed to the Guide for the Care and Use of Laboratory Animals published by the National Institutes of Health and were approved by the Institutional Animal Care and Use Committee of Hebei Medical University.

\section{Hematoxylin and Eosin ( $\mathrm{H}$ and E) Staining and Immunohistochemistry}

The aortas were fixed with $4 \%$ polyoxymethylene, dehydrated by ethanol, and placed in xylene, and then embedded in paraffin wax and sliced. The sections were baked at $65^{\circ} \mathrm{C}$ for $4 \mathrm{~h}$, dewaxed, hematoxylin stained for $15 \mathrm{~min}$, and decolorized with hydrochloric acid alcohol solution for $5 \mathrm{~s}$. Then, the sections were stained with eosin for $2 \mathrm{~min}$ and dehydrated. Finally, the sections were mounted in neutral gel and the tissue sections were observed under a microscope.

The immunohistochemical analyses were processed according to standard procedures. In short, the slices were baked and then dewaxed in xylene and hydrated in gradient alcohol. Then, $3 \% \mathrm{H}_{2} \mathrm{O}_{2}$ was added to the sections to remove endogenous peroxidase. Immunostained sections were preincubated with $5 \%$ normal goat serum and then incubated with specific primary antibodies against PCNA (1:500, ab92552; Abcam), MMP-9 (1:500, sc-13520; SantaCruz, USA), SM22 $\alpha$ (1:500, ab14106; Abcam), and SM- $\alpha$-actin (1:500, ab7817; Abcam). The sections were incubated with the horseradish peroxidase streptavidin biotinylated secondary antibody followed by diaminobenzidine (DAB kit, ZSGB-BIO, China). For the negative controls, the primary antibody was replaced with non-immune rabbit or mouse serum. Staining intensities were determined by measurement of the integrated optical density with light microscopy using a computer-based Image-Pro Morphometric System. The results are expressed as the mean value of at least three randomly chosen slides in each group.

\section{Statistical Analysis}

Data analysis was performed using SPSS version 16.0 or Graphpad Prism 6 software. Data are presented as means \pm standard deviation from at least three independent experiments, and each independent experiment was repeated at least three times to obtain the mean. Normally distributed datasets were analyzed with the unpaired Student's $t$-test for two independent groups or paired $t$-test for two dependent groups, and the one-way analysis of variance followed by the post Bonferroni's multiple comparisons test for $\geq 3$ groups. For all statistical comparisons, a value of $P<0.05$ was considered statistically significant and denoted with one, two, and three asterisks when lower than $0.05,0.01$, and 0.001 , respectively.

\section{RESULTS}

\section{Lysozyme Promoted the Effects of PNS on Inhibition of VSMC Viability}

To investigate the effect of PNS combined with lysozyme on viability of VSMCs, we conducted CCK-8 assays. As displayed in Figure 1A, PDGF-BB significantly promoted VSMC viability, and after pretreatment of VSMC with different concentrations of PNS, 15, 30, and $60 \mu \mathrm{g} / \mathrm{ml}$ PNS for $24 \mathrm{~h}$ had no effect on VSMC viability, whereas 120 and $240 \mu \mathrm{g} / \mathrm{ml}$ PNS significantly inhibited cell viability, suggesting that PNS inhibited VSMC viability in a concentration-dependent manner, similar with the previous studies (19).

Next, VSMCs were pretreated with $60 \mu \mathrm{g} / \mathrm{ml}$ PNS, $60 \mu \mathrm{g} / \mathrm{ml}$ lysozyme, and the mixture of PNS and lysozyme $(30 \mu \mathrm{g} / \mathrm{ml}$ PNS $+30 \mu \mathrm{g} / \mathrm{ml}$ lysozyme) for 6,12 , and $24 \mathrm{~h}$, respectively. As shown in Figure 1B, PNS or lysozyme used alone had no effect on the viability of VSMC stimulated by PDGF-BB, but the combination of PNS and lysozyme significantly inhibited cell viability in a time-dependent manner. These data indicated that the joint application of PNS and lysozyme repressed viability of VSMCs.

\section{GS-Re May Be the Main Ingredients of PNS That Contributes to the Decreased VSMC Viability Through Joint Application With Lysozyme}

To screen the main ingredients of PNS that inhibit VSMC viability through joint application with lysozyme, we determined the effect of the synergism of lysozyme and GS-Rb1, NG-R1, GS-Rg1, GS-Re, or GS-Rd, the five main ingredients of PNS, on VSMC viability. Compared with the DMSO control group, the viability of VSMCs was not changed with the addition of $30 \mu \mathrm{g} / \mathrm{ml}$ lysozyme, GS-Rb1, NG-R1, GS-Rg1, GS-Re, or GS-Rd, and the viability was also not affected by the joint application of $15 \mu \mathrm{g} / \mathrm{mL}$ lysozyme and $15 \mu \mathrm{g} / \mathrm{ml} \mathrm{GS-Rb1,} \mathrm{NG-}$ R1, GS-Rg1, or GS-Rd. However, this response was significantly attenuated by the synergism of GS-Re and lysozyme $(15 \mu \mathrm{g} / \mathrm{mL}$ GS-Re+15 $\mu \mathrm{g} / \mathrm{ml}$ lysozyme) (Figure 2), meaning that GS-Re, but not GS-Rb1, NG-R1, GS-Rg1, or GS-Rd, may be the main ingredients of PNS in the joint application with lysozyme.

\section{Mass Spectral Studies on the Interaction Between GS-Re and Lysozyme}

A series of mass peaks of different mass to charge ratios, including the peaks at $\mathrm{m} / \mathrm{z} 1,193.2,1,301.7,1,431.7,1,590.6$, and 1,789.1, displaying multicharge distribution of lysozyme from $(\mathrm{M}+8 \mathrm{H}) 8+$ to $(\mathrm{M}+12 \mathrm{H}) 12+$, represents the $+12,+11,+10,+9$, and +8 charge states of lysozyme, respectively, after the lysozyme solution detected by electrospray ionization-mass spectrometry, in which peaks of +10 charge number were the most obvious 
A

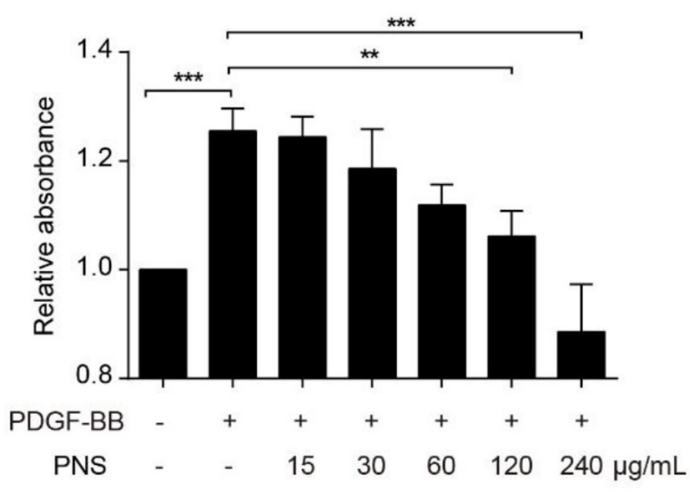

B

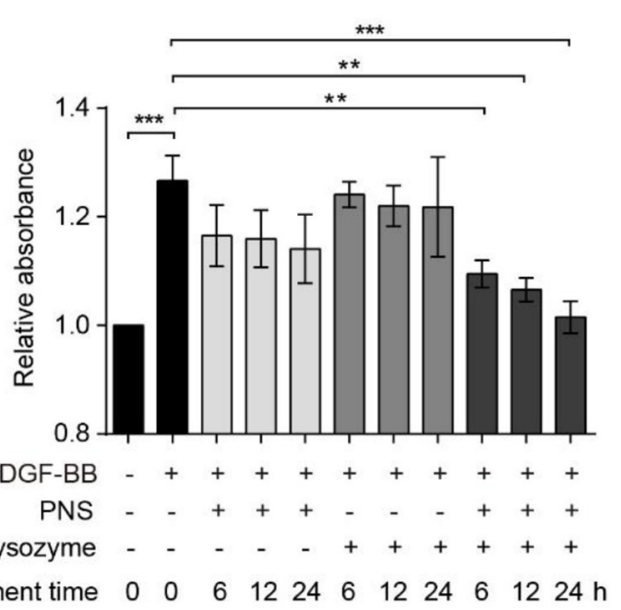

FIGURE 1 | Lysozyme promoted the activity of Panax notoginseng saponins (PNS) on inhibition of vascular smooth muscle cell (VSMC) viability. (A) Cell counting kit-8 (CCK-8) for the viability of VSMCs, cultured in serum-starved medium containing 15, 30, 60, 120, and $240 \mu \mathrm{g} / \mathrm{mL}$ PNS or dimethyl sulfoxide (DMSO) for $24 \mathrm{~h}$, and then stimulated by platelet derived growth factor BB (PDGF-BB) for $24 \mathrm{~h}$ or remained untreated. (B) CCK-8 for the viability of VSMCs, cultured in serum-starved medium containing $60 \mu \mathrm{g} / \mathrm{ml}$ PNS, $60 \mu \mathrm{g} / \mathrm{ml}$ lysozyme, or the mixture of PNS and lysozyme ( $30 \mu \mathrm{g} / \mathrm{ml} \mathrm{PNS}+30 \mu \mathrm{g} / \mathrm{ml}$ lysozyme) for 6,12 , and $24 \mathrm{~h}$, and then stimulated by PDGF-BB for $24 \mathrm{~h}$ or remained untreated. Data are presented as mean $\pm \mathrm{SD},{ }^{* *} P<0.01,{ }^{* \star *} P<0.001$.

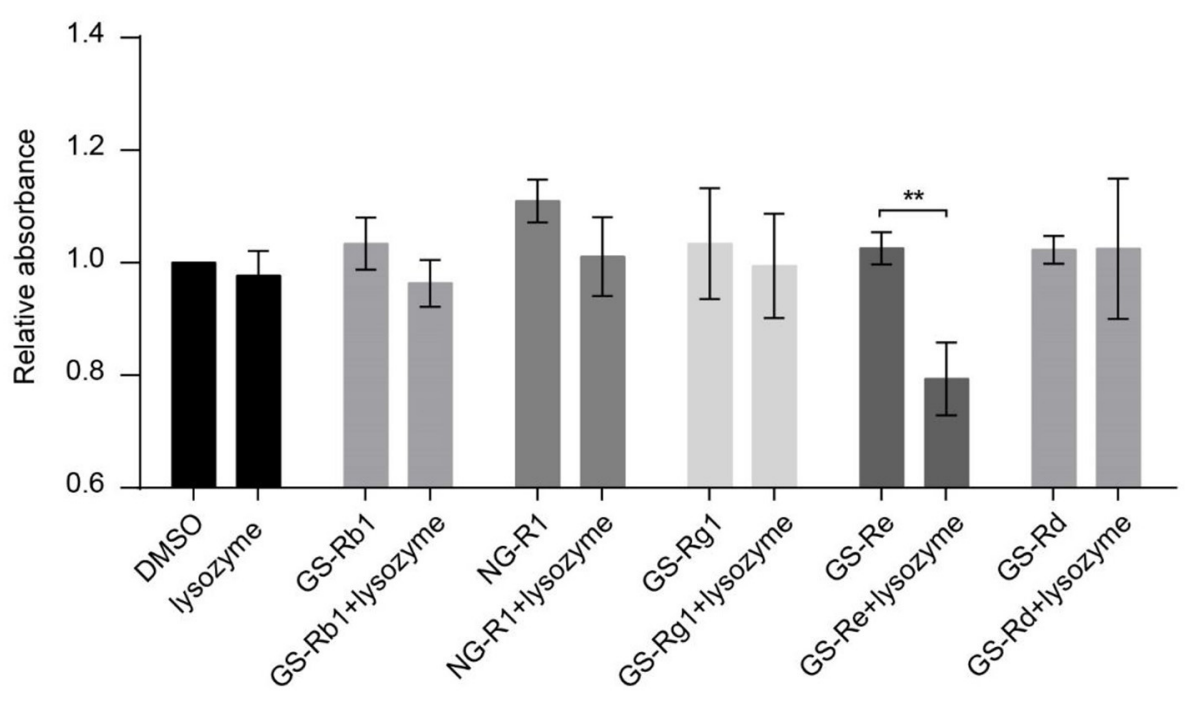

FIGURE 2 | GS-Re may be the main ingredients of PNS that contributes to the decreased VSMC viability through combining with lysozyme. CCK-8 for the viability of VSMCs, cultured in serum-starved medium containing $30 \mu \mathrm{g} / \mathrm{ml}$ lysozyme, GS-Rb1, NG-R1, GS-Rg1, GS-Re or GS-Rd, or the mixture of lysozyme and five ingredients of PNS $(15 \mu \mathrm{g} / \mathrm{ml}$ lysozyme $15 \mu \mathrm{g} / \mathrm{ml}$ GS-Rb1, NG-R1, GS-Rg1, GS-Re, or GS-Rd, respectively) for $24 \mathrm{~h}$, and then stimulated by PDGF-BB for $24 \mathrm{~h}$. Data are presented as mean $\pm S D,{ }^{\star \star} P<0.01$.

(Figure 3A). The average molecular weight of lysozyme was $14,306.8$, which was close to the theoretical molecular weight.

The molecular ion peaks of various complexes composed of GS-Re and lysozyme were detected by mass spectrometry, suggesting that GS-Re might be combined with lysozyme and the supramolecular complexes were formed (Figures 3B-D). The peaks at $\mathrm{m} / \mathrm{z} 1,621.0$ and 1,715 indicated the +10 charge states of $1: 2$ and 1:3 complex of GS-Re with lysozyme, respectively (Figures 3B,C). In Figures 3C,D, the concentration ratio of lysozyme to GS-Re increased from 1:8 to $1: 12$, and with the increased concentration ratio, the molecular ion peak intensity ratio of supramolecular complex formed by one molecule of lysozyme and two molecules of GS-Re to free lysozyme increased from 60.7 to $107.7 \%$. Compared with Figures 3B,C, another strong signal at the peak of 1905.5 was detected in Figure 3D, which may be associated with the supramolecular complex with +10 charges formed by one molecule of lysozyme and five molecules of GS-Re. These data suggested the combined ability 
Huang et al.

Lysozyme Promotes PNS Activity

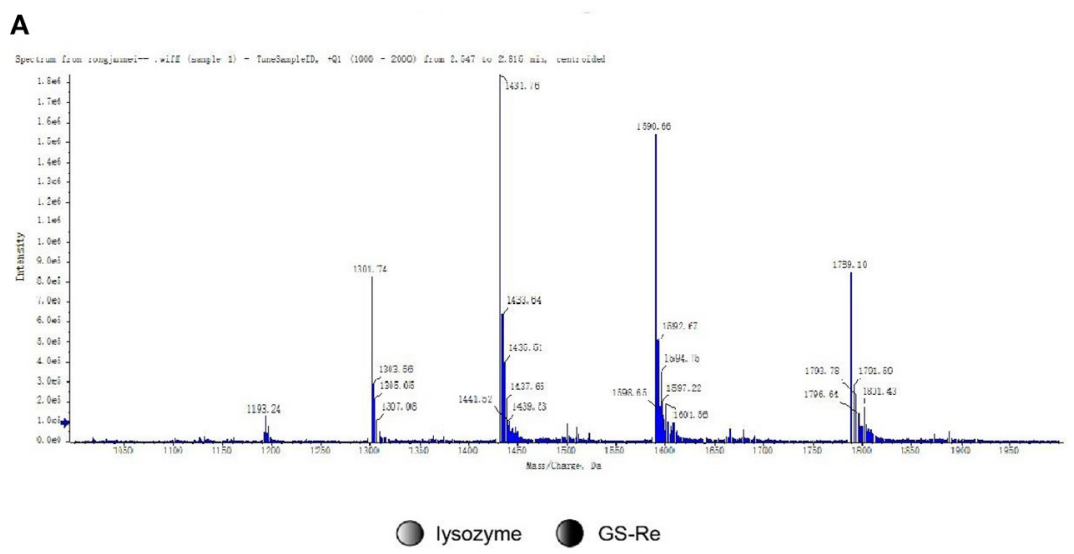

B

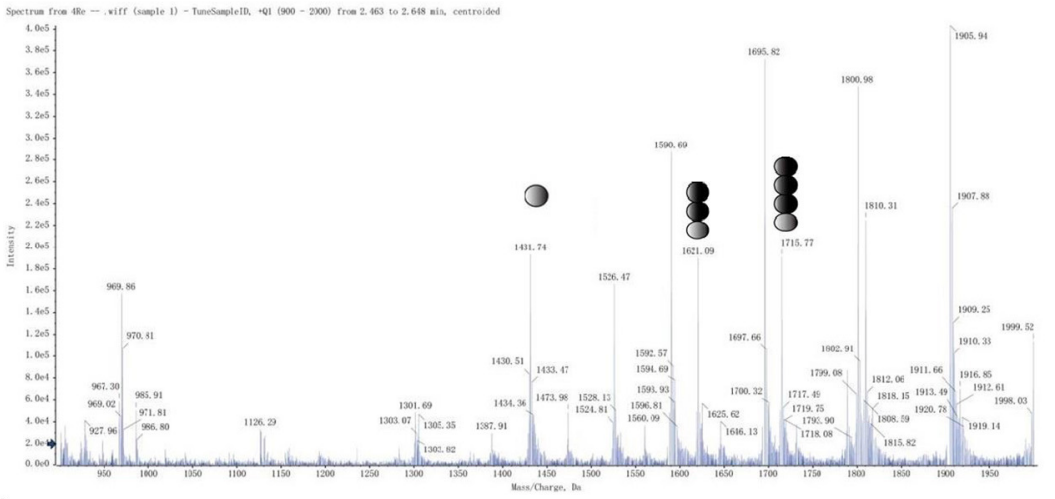

C

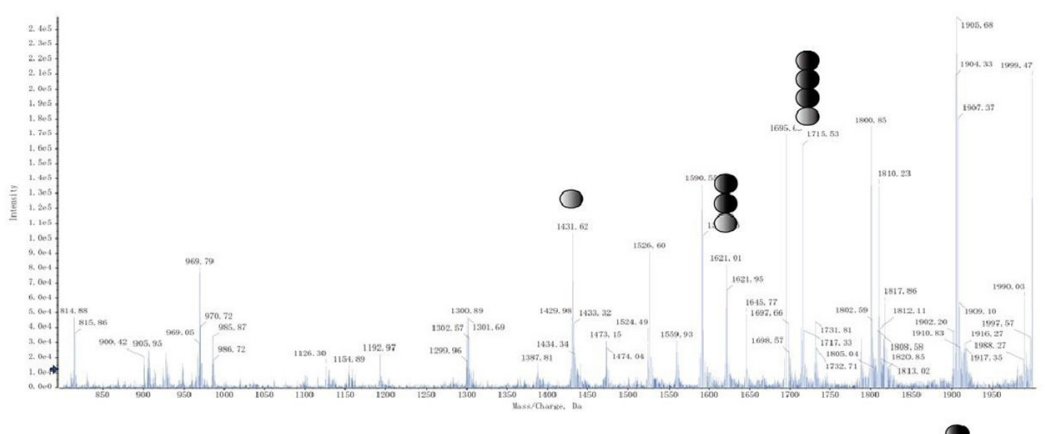

D

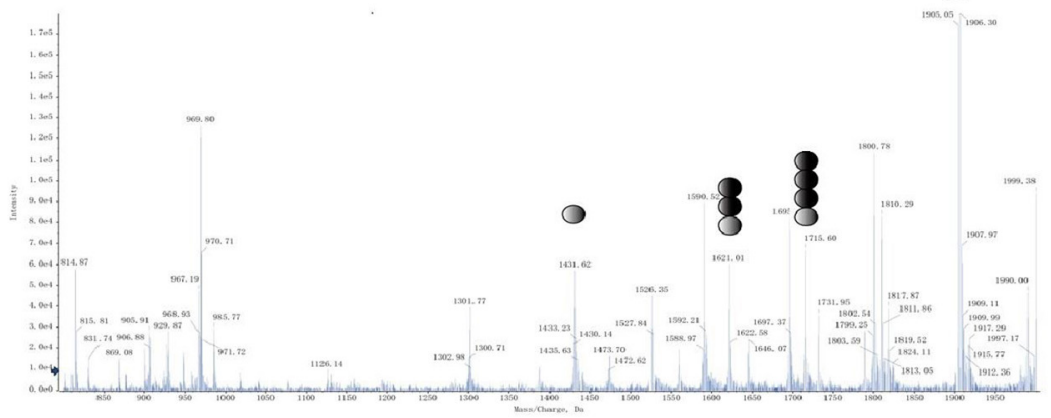

FIGURE 3 | Mass spectral studies on the interaction between GS-Re and lysozyme. The interaction between GS-Re and lysozyme was determined in the condition of detector voltage $3 \mathrm{KV}$, capillary temperature $200^{\circ} \mathrm{C}$, the ionization temperature $300^{\circ} \mathrm{C}$, sheath gas (nitrogen) flow 35 arb, and sweep gas (nitrogen) flow 10 arb. (A) Lysozyme, $C_{(\text {(lysozyme) }}=5.0 \times 10^{-5} \mathrm{~mol} / \mathrm{L}$; (B) lysozyme+GS-Re, $C_{(\text {lysozyme) }}=5.0 \times 10^{-5} \mathrm{~mol} / \mathrm{L}, C_{(\mathrm{GS}-\mathrm{Re})}=2.0 \times 10^{-4} \mathrm{~mol} / \mathrm{L}$; (C) lysozyme+GS-Re, $C_{(\text {(lysozyme) }}=5.0$ $\times 10^{-5} \mathrm{~mol} / \mathrm{L}, C_{(\mathrm{GS}-R e)}=4.0 \times 10^{-4} \mathrm{~mol} / \mathrm{L} ;$ (D) lysozyme+GS-Re, $C_{(\text {(lysozyme) }}=5.0 \times 10^{-5} \mathrm{~mol} / \mathrm{L}, C_{(\mathrm{GS}-\mathrm{Re})}=6.0 \times 10^{-4} \mathrm{~mol} / \mathrm{L}$.

Frontiers in Nutrition | www.frontiersin.org

6

December 2021 | Volume 8 | Article 795888 

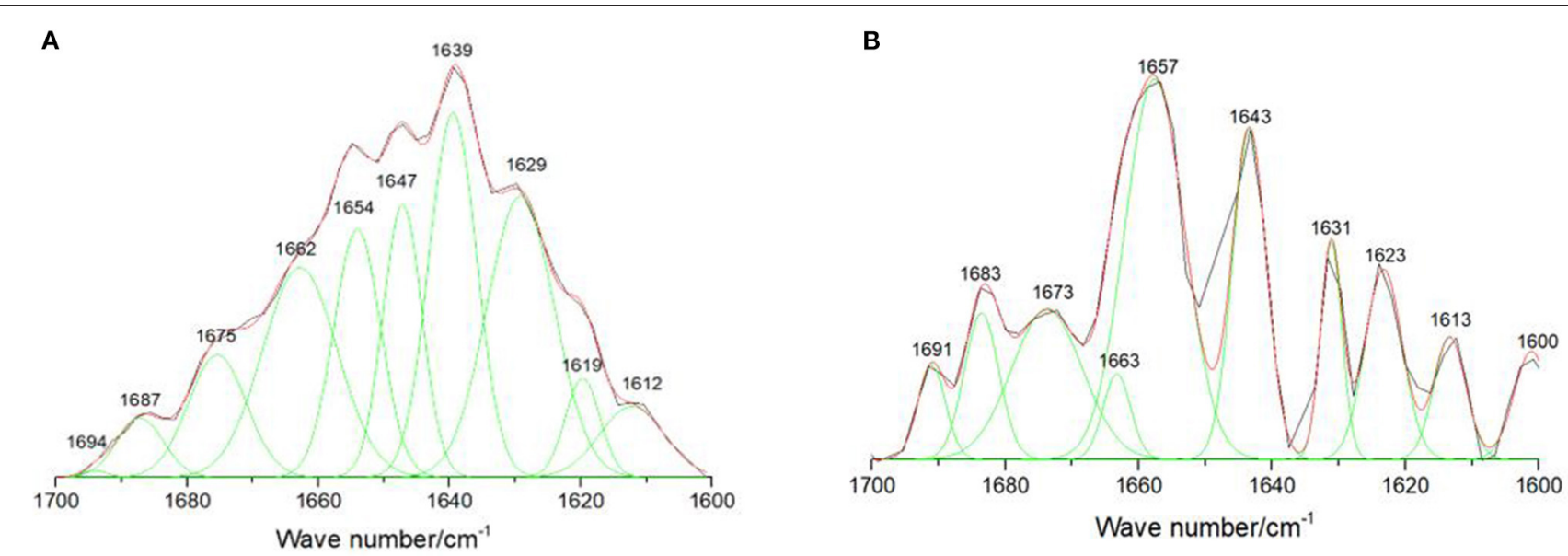

FIGURE 4 | Effect of GS-Re on the secondary structure of lysozyme. The curve-fitting figures of attenuated total reflectance Fourier transform infrared spectroscopy (ATR-FTIR) differential spectra within the scope of 1,700-1,600 $\mathrm{cm}^{-1}$ were fitted by the Gauss curve fitting, and the secondary structure contents of lysozyme were calculated from the areas of the individual assigned bands and their fraction of the total area. (A) Lysozyme, $C_{(\text {lysozyme })}=5.0 \times 10^{-5}$ mol/L; (B)

(lysozyme+GS-Re)-GS-Re, $C_{(\text {lysozyme })}=5.0 \times 10^{-5} \mathrm{~mol} / \mathrm{L}, C_{(\mathrm{GS}-\mathrm{Re})}=5.0 \times 10^{-5} \mathrm{~mol} / \mathrm{L}$. ATR-FTIR curve-fitting differential spectra with the resolution of $4 \mathrm{~cm}^{-1}$ and 60 scans in the range from 1,000 to $2,000 \mathrm{~cm}^{-1}$.

A

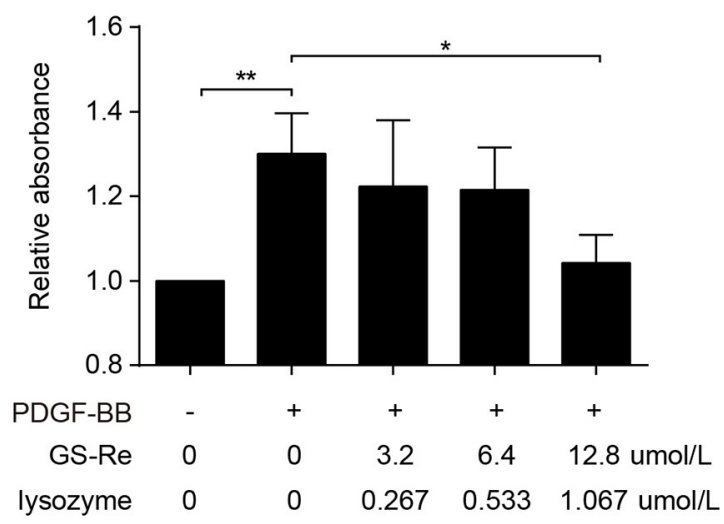

B

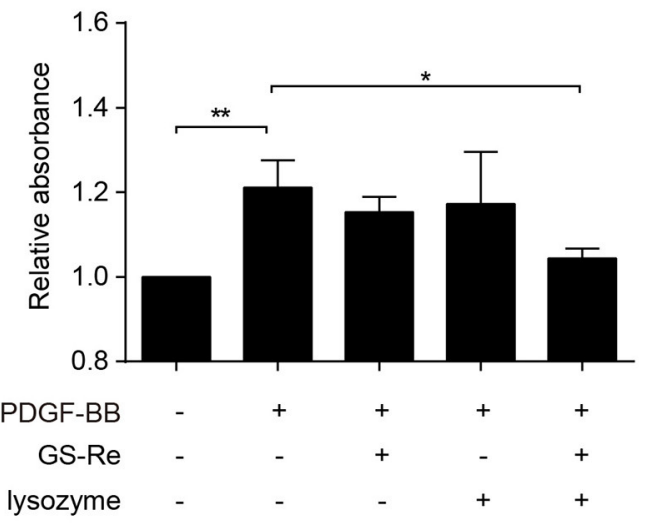

FIGURE 5 | The combined use of GS-Re and lysozyme inhibits the viability of VSMCs. (A) CCK-8 for the viability of VSMCs, cultured in serum-starved medium containing the mixture of GS-Re and lysozyme (the molar ratio of GS-Re/lysozyme was 12:1) for $6 \mathrm{~h}$, and then stimulated by PDGF-BB for $24 \mathrm{~h}$ or remained untreated. (B) CCK-8 for the viability of VSMCs, cultured in serum-starved medium containing $12.8 \mu \mathrm{mol} / \mathrm{L}$ GS-Re,1.067 $\mu \mathrm{mol} / \mathrm{L}$ lysozyme or the mixture of GS-Re and lysozyme (12.8 $\mu \mathrm{mol} / \mathrm{L}$ GS-Re+1.067 $\mu \mathrm{mol} / \mathrm{L}$ lysozyme) for $24 \mathrm{~h}$, and then stimulated by PDGF-BB for $24 \mathrm{~h}$ or remained untreated. Data are presented as mean \pm $\mathrm{SD},{ }^{\star} P<0.05,{ }^{\star \star} P<0.01$.

between GS-Re and lysozyme could be increased with the high concentration ratio of GS-Re to lysozyme.

\section{Effect of GS-Re on the Secondary Structure of Lysozyme}

It is important to study the change of lysozyme $\alpha$-helix structure, because the active site of lysozyme is mainly in helices region. To further explore whether the formation of this supramolecular complex would influence the secondary structure of lysozyme or not, we performed infrared spectroscopy on lysozyme. The absorption bands in the amide I region corresponding to $\alpha$-helix $\left(1,642-1,660 \mathrm{~cm}^{-1}\right), \beta$-sheet $\left(1,613-1,637 \mathrm{~cm}^{-1}\right.$ and $\left.1,682-1,689 \mathrm{~cm}^{-1}\right), \beta$-turn $\left(1,662-1,700 \mathrm{~cm}^{-1}\right)$, and disordered $\left(1,637-1,645 \mathrm{~cm}^{-1}\right)$ structures were observed in the ATRFTIR spectra $(15,21)$. The correlative differential spectra and Gaussian fitting plots of lysozyme and (GS-Re-lysozyme)-GSRe were shown in Figure 4. The relative contents of lysozyme secondary structure were changed after adding GS-Re. The average relative contents of lysozyme $\alpha$-helix in the presence of GS-Re significantly increased from 24.1 to $32.4 \%$ with $\beta$-sheet decreasing from 32.4 to $26.0 \%$, and the significant changes on the lysozyme $\alpha$-helix and $\beta$-sheet relative contents in the presence of GS-Re with $p$-values $<0.05$ indicated the interaction between lysozyme and GS-Re induced folding of lysozyme peptides 
and changes of lysozyme conformation, which may affect the biological function of lysozyme.

\section{Combined Use of GS-Re and Lysozyme Inhibits the Phenotype Transformation of VSMCs}

To further evaluate the effects of GS-Re combined with lysozyme on viability of VSMCs, the mixture of GS-Re and lysozyme (the molar ratio of GS-Re:lysozyme was $12: 1 ; 3.2 \mu \mathrm{mol} / \mathrm{L}$ GS$\mathrm{Re}+0.267 \mu \mathrm{mol} / \mathrm{L}$ lysozyme, $6.4 \mu \mathrm{mol} / \mathrm{L}$ GS-Re+0.533 $\mu \mathrm{mol} / \mathrm{L}$ lysozyme, and $12.8 \mu \mathrm{mol} / \mathrm{L}$ GS-Re+1.067 $\mu \mathrm{mol} / \mathrm{L}$ lysozyme) was used. Results from CCK-8 assay showed that the mixture of $3.2 \mu \mathrm{mol} / \mathrm{L}$ GS-Re+0.267 $\mu \mathrm{mol} / \mathrm{L}$ lysozyme and the mixture of $6.4 \mu \mathrm{mol} / \mathrm{L}$ GS-Re $+0.533 \mu \mathrm{mol} / \mathrm{L}$ lysozyme had no effect on the viability of VSMCs, and the mixture of $12.8 \mu \mathrm{mol} / \mathrm{L}$ GS-Re+1.067 $\mu \mathrm{mol} / \mathrm{L}$ lysozyme significantly decreased the cell viability (Figure 5A), whereas $12.8 \mu \mathrm{mol} / \mathrm{L}$ GS-Re or 1.067 $\mu \mathrm{mol} / \mathrm{L}$ lysozyme had no effect on the activity of VSMC (Figure 5B).

Aberrant proliferation is a hallmark of VSMC phenotype transformation during vascular injury $(1,2)$. To further investigate the possible mechanisms underlying the effects of PNS and lysozyme synergism on modulation of VSMC phenotype, the expression of SM- $\alpha$-actin and SM22 $\alpha$, the typical markers of differentiation phenotypes, and the expression of MMP-9 and PCNA, the typical markers of synthetic phenotypes, were examined through qRT-PCR and Western blot. As shown in Figures $6 \mathrm{~A}-\mathrm{C}$, the expression of SM- $\alpha$-actin and SM22 $\alpha$ were clearly determined in the control group and were significantly downregulated in PDGF-BB-stimulated VSMCs, agreeing with previous studies (20). Compared with PDGF-BB group, the expression of SM- $\alpha$-actin and SM22 $\alpha$ had almost no changes stimulated by $12.8 \mu \mathrm{mol} / \mathrm{L}$ GS-Re or $1.067 \mu \mathrm{mol} / \mathrm{L}$ lysozyme along but increased by 12:1 mixture of GS-Re and lysozyme $(12.8 \mu \mathrm{mol} / \mathrm{L}$ GS-Re $+1.067 \mu \mathrm{mol} / \mathrm{L}$ lysozyme $)$. At the same time, PDGF-BB increased the expression of MMP-9 and PCNA, which was reversed by the mixture of GS-Re and lysozyme (Figures 6C-E).

Except for proliferation, increased migration is another key process during phenotype transformation of VSMCs $(20,25)$. To further address the role of PNS and lysozyme synergism in VSMC migration, we performed $2 \mathrm{D}$ wound-healing and $3 \mathrm{D}$ transwell migration assays. As shown in Figure 7A, the 12:1 mixture of GS-Re and lysozyme inhibited PDGF-BB-induced VSMC wound closure and migration, and GS-Re or lysozyme used alone almost has no effect on it. Results from Boyden chamber transwell assay further confirmed the inhibitory effect of the mixture (Figure 7B). Taken together, these results suggested that lysozyme enhances the activity of GS-Re on the inhibition of VSMC phenotypic transition.

\section{Mixture of GS-Re and Lysozyme Ameliorates AAA Progression}

The phenotypic transition of VSMCs exhibits at the early onset of the pathology of aortic aneurysms (22). To evaluate the therapeutic potential of the mixture of GS-Re and lysozyme on
VSMC phenotypic transition in vivo, $\mathrm{CaCl}_{2}$-induced $\mathrm{C} 57 \mathrm{BL} / 6 \mathrm{~J}$ mouse model of AAA was used. Morphometric analysis showed that $\mathrm{CaCl}_{2}$ markedly increased the aortic expansion, and compared with the model group, treatment with GS-Re (50 $\mathrm{mg} / \mathrm{kg} /$ day) alone could slightly reduce the enlargement of arteries, whereas the mixture of GS-Re and lysozyme (50 $\mathrm{mg} / \mathrm{kg} /$ day, the molar ratio of GS-Re/lysozyme was 12:1) decreased the diameter of arteries significantly (Figures 8A,B). $\mathrm{HE}$ and Elastic-Van Gieson (EVG) staining also showed that the mixture of GS-Re and lysozyme preserved vascular tissue integrity and reduced tissue damage and elastin degradation (Figure 8C). Furthermore, the upregulated expression of MMP9 and PCNA and downregulated expression of SM- $\alpha$-actin and SM22 $\alpha$ were observed via immunohistochemical staining in the $\mathrm{CaCl}_{2}$-treated group, which were reversed remarkably by the mixture of GS-Re and lysozyme (Figure 8D). These findings indicate that the combination of GS-Re and lysozyme may be involved in the phenotype transformation of VSMCs during the pathogenesis of AAA.

\section{DISCUSSION}

Cardiovascular disease is the leading cause of death worldwide, and compelling evidence has indicated that vascular remodeling represents promising potential therapeutic targets for cardiovascular diseases. As the key cells implicated in vascular remodeling, VSMCs are multifunctional mesenchyme derived from the mesoderm during embryonic development and plays an important role in maintaining vascular tone, blood pressure, and blood flow distribution. Unlike skeletal muscle and cardiomyocytes, VSMCs are highly plastic and susceptible to phenotypic switching from a contractile phenotype to a synthetic, secretory, inflammatory, proteolytic, or even osteochondrogenic phenotype upon various stimulations $(1,2,4,26-28)$, and the dedifferentiated VSMCs are prone to proliferation and migration, produce more inflammatory cytokines and reactive oxygen species, and exhibit greater proteolytic activity than contractile VSMCs (20, 26, 29-32). Therefore, exploring the effective therapeutic strategy for blockade of VSMC phenotype transformation is helpful for treatment of cardiovascular diseases.

Lysozyme, also referred to as muramidase or $\mathrm{N}$ acetylmuramic hydrolase, is widely distributed in egg whites of birds and poultry, as well as tears, saliva, plasma, and milk of mammals. In the food or pharmaceutical industries, lysozyme has been widely used against bacteria because of its hydrolysis of $\beta$-1,4-glycosidic linkages in specific Gram-positive bacteria wall. Together with the unique characteristics, for instance, higher natural abundance, stability, small size, monomeric protein, positive charge, and drug binding ability, lysozyme has emerged as a model protein for investigating the interaction with different small molecules, pharmaceutical drugs, metal ions, and dyes, as well as in studying the relationship between protein folding and dynamics, structure-function relationship, and cell-to-cell interaction $(12,33)$. Our previous study has demonstrated that the combination of caffeine and lysozyme 
A

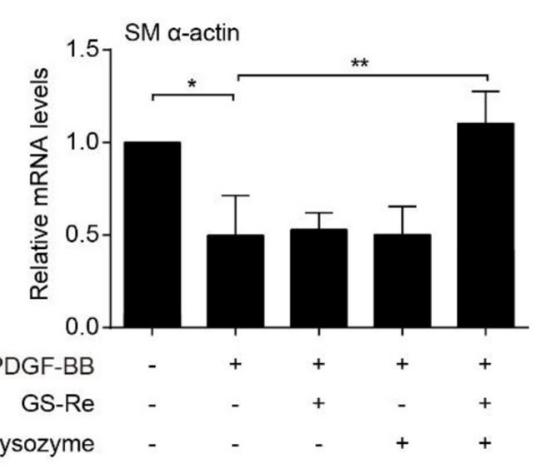

C

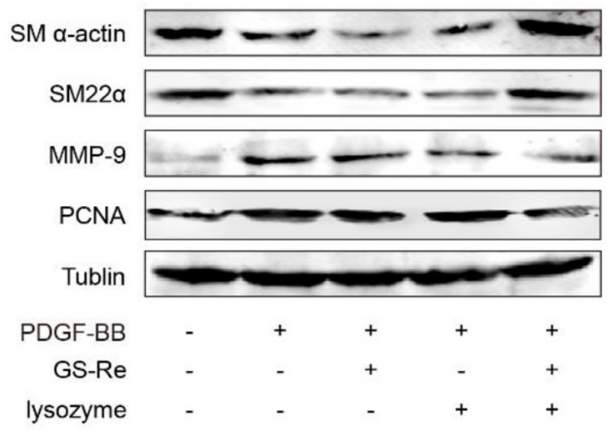

D

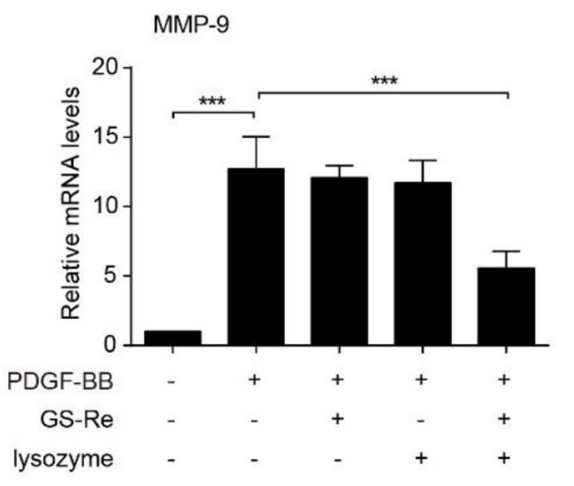

B
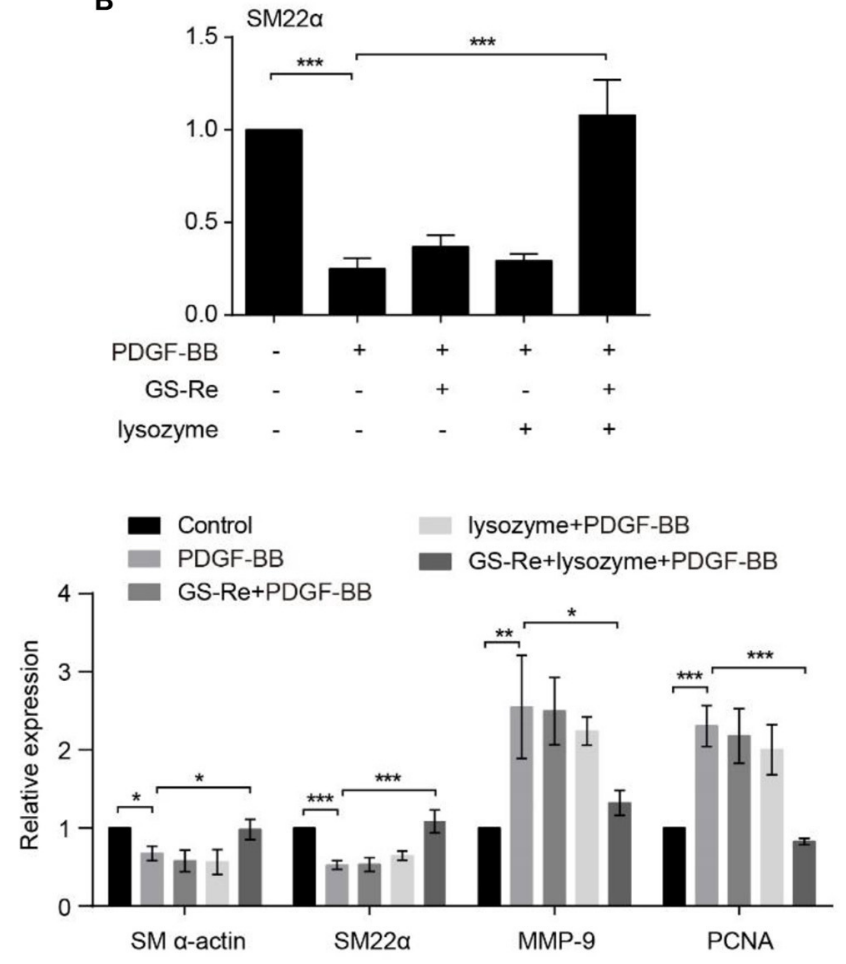

E

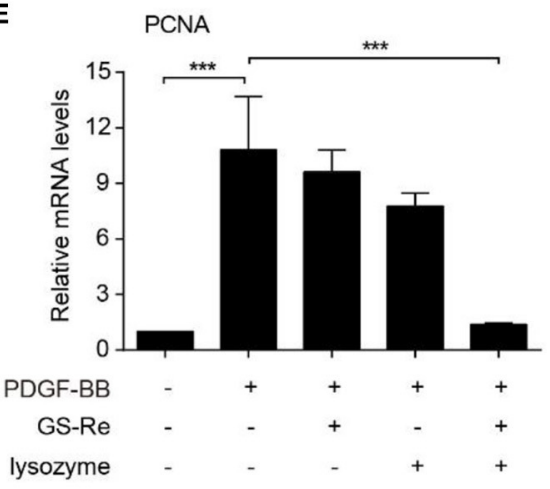

FIGURE 6 | The combined use of GS-Re and lysozyme inhibits the phenotype transformation of VSMCs. Real-time polymerase chain reaction (PCR) (A, B, D, E) or Western blot (C) analysis of the expression of SM- $\alpha$-actin, SM22 $\alpha$, matrix metallopeptidase 9 (MMP-9), and proliferating cell nuclear antigen (PCNA) in VSMCs, cultured in serum-starved medium containing $12.8 \mu \mathrm{mol} / \mathrm{L}$ GS-Re, $1.067 \mu \mathrm{mol} / \mathrm{L}$ lysozyme, or the mixture of GS-Re and lysozyme (12.8 $\mu \mathrm{mol} / \mathrm{L}$ GS-Re+1.067 $\mu \mathrm{mol} / \mathrm{L}$ lysozyme) for $6 \mathrm{~h}$, and then stimulated by PDGF-BB for $6 \mathrm{~h}$ (real-time PCR), $24 \mathrm{~h}$ (Western blot), or remained untreated. Data are presented as mean \pm SD, ${ }^{*} P$ $<0.05,{ }^{* *} P<0.01,{ }^{* \star *} P<0.001$.

through electrostatic interaction increased the concentration of caffeine on the surface of HepG2 cells, showing synergistic effects and accelerating HepG2 apoptosis (18). According to the Traditional Chinese Medicine, PNS improves blood circulation, removes blood stasis, nourishes blood, stops bleeding, eliminates swelling, and relieves pain; so, it has been most widely used to treat cardiovascular and cerebrovascular diseases $(6,34,35)$. In the current study, we revealed that 15,30 , and $60 \mu \mathrm{g} / \mathrm{ml}$ PNS did not significantly decrease PDGF-BB-induced viability of VSMCs, and 120 and $240 \mu \mathrm{g} / \mathrm{ml}$ PNS significantly inhibited it. Then, the highest concentration of PNS that did not influence cell viability $(60 \mu \mathrm{g} / \mathrm{ml}), 60 \mu \mathrm{g} / \mathrm{ml}$ lysozyme, and the mixture of PNS and lysozyme $(30 \mu \mathrm{g} / \mathrm{ml}$ PNS $+30 \mu \mathrm{g} / \mathrm{ml}$ lysozyme $)$ were selected to treat VSMCs, and when the VMSCs were treated by the mixture, we found that lysozyme promotes the activity of PNS on the inhibition of VSMC viability. Based on the ability of lysozyme to easily bind with drug molecules and increase the efficacy $(17,18)$, we predicted that some of the PNS components may play a key role in this process by binding to lysozyme. Results from CCK- 8 assay indicated that, among the five main ingredients of 
A
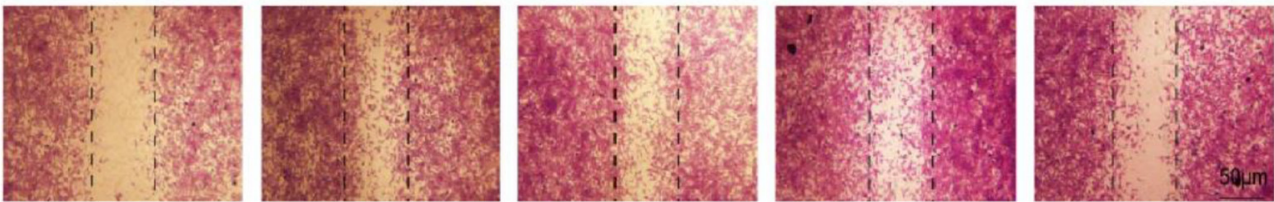

$\begin{aligned} \text { PDGF-BB } & - \\ \text { GS-Re } & - \\ \text { lysozyme } & -\end{aligned}$
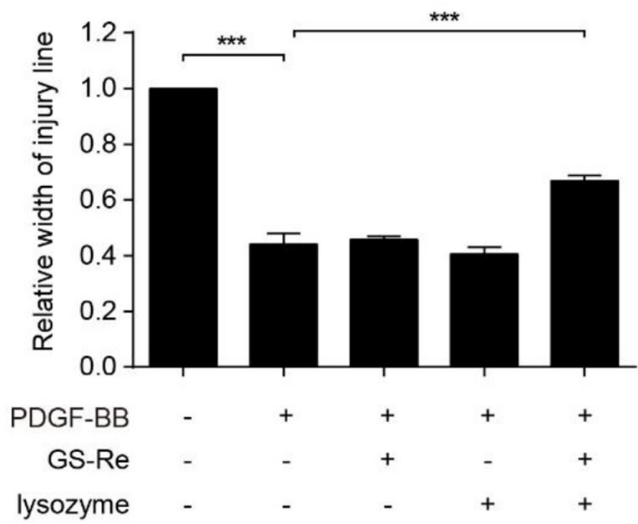

B
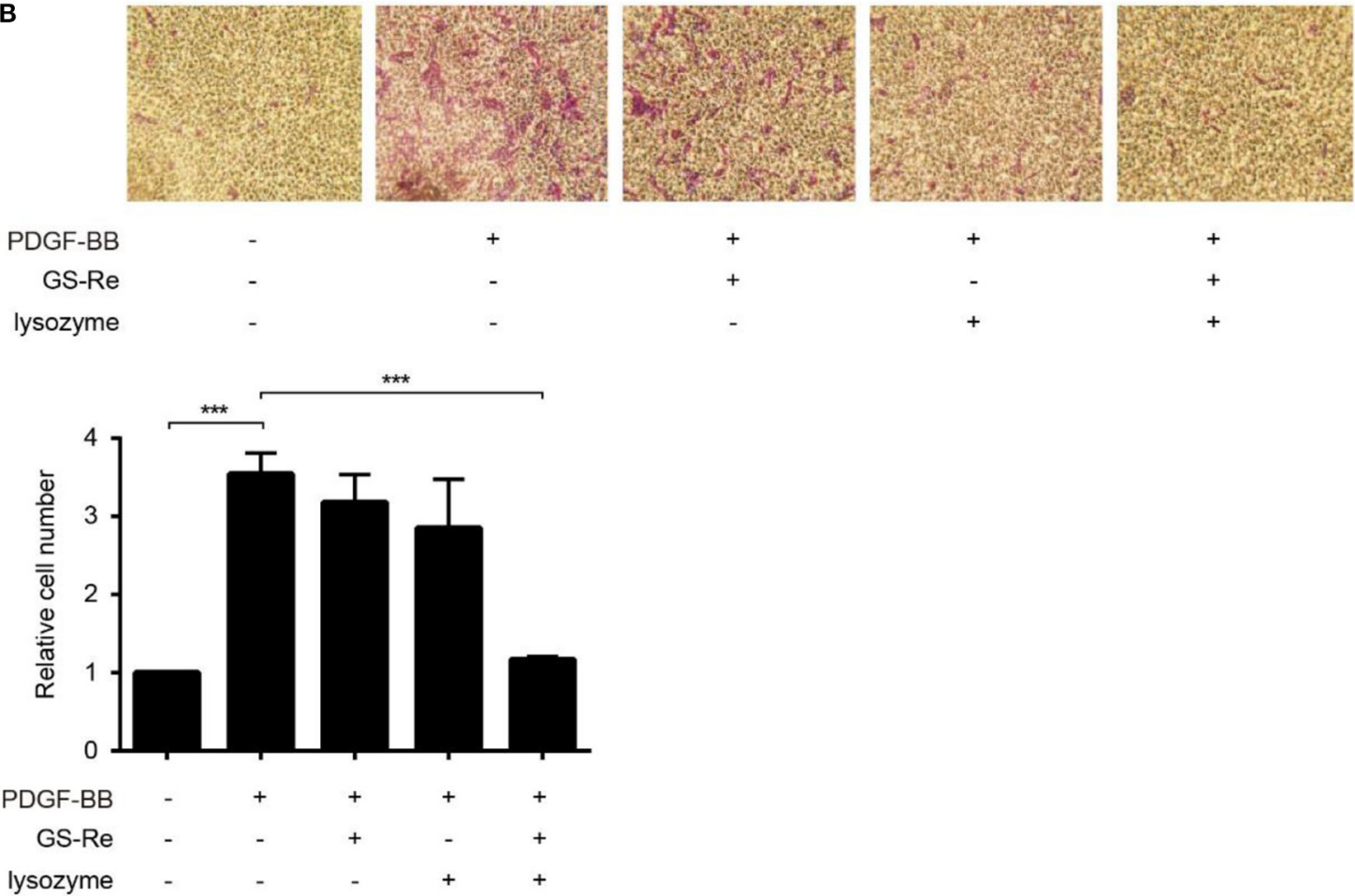

FIGURE 7 | The combined use of GS-Re and lysozyme inhibits VSMC migration. The wound-healing (A) and transwell assay (B) for the migration of VSMCs, cultured in serum-starved medium containing $12.8 \mu \mathrm{mol} / \mathrm{L}$ GS-Re, $1.067 \mu \mathrm{mol} / \mathrm{L}$ lysozyme, or the mixture of GS-Re and lysozyme $(12.8 \mu \mathrm{mol} / \mathrm{L}$ GS-Re+1.067 $\mu \mathrm{mol} / \mathrm{L}$ lysozyme) for $6 \mathrm{~h}$, and then stimulated by PDGF-BB or remained untreated. Data are presented as mean $\pm \mathrm{SD}$, ${ }^{\star \star \star} P<0.001$. 
A
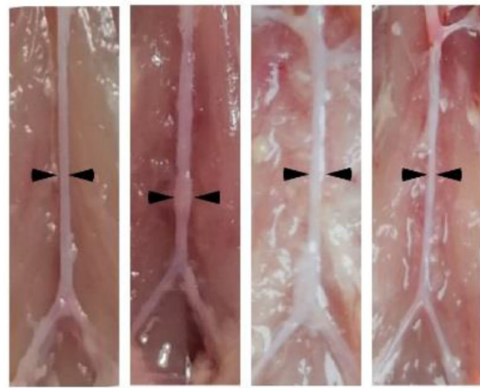

$\mathrm{CaCl}$

GS-Re

lysozyme

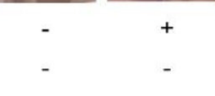

C

HE
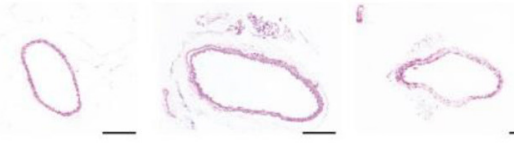

HE

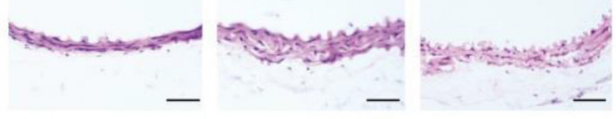

EVG
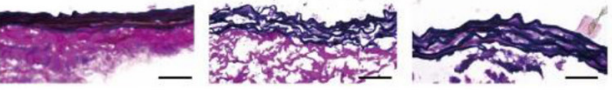

$\mathrm{CaCl}_{2}$

GS-Re

lysozyme

D MMP-9
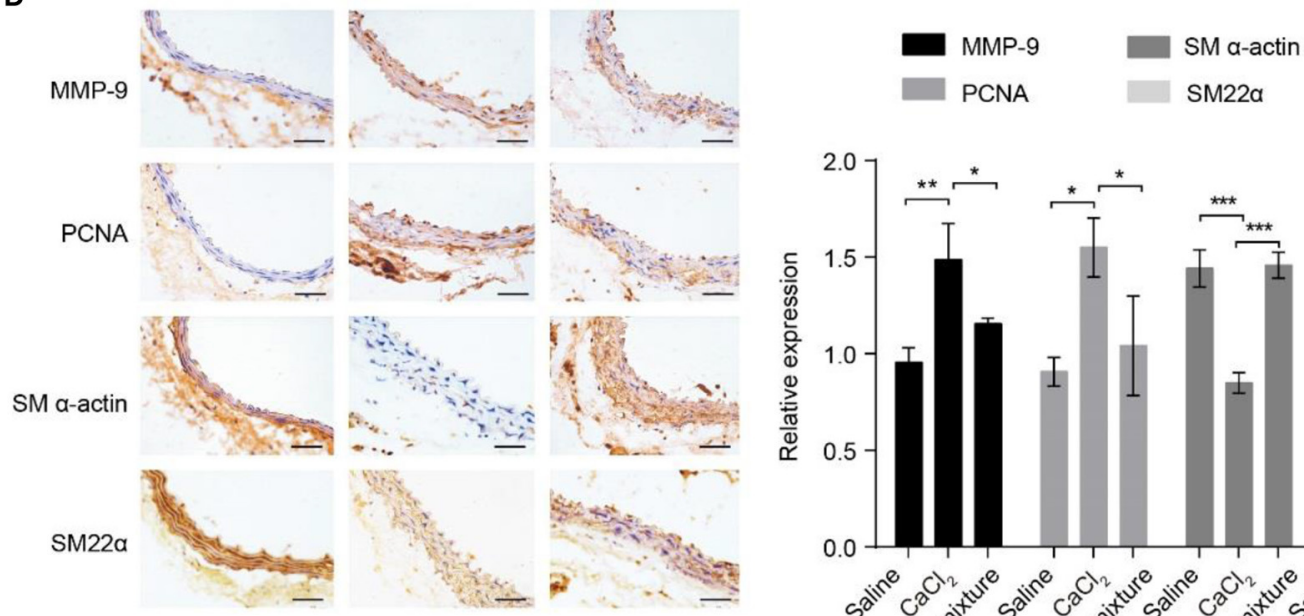

$\mathrm{CaCl}_{2}$

lysozyme

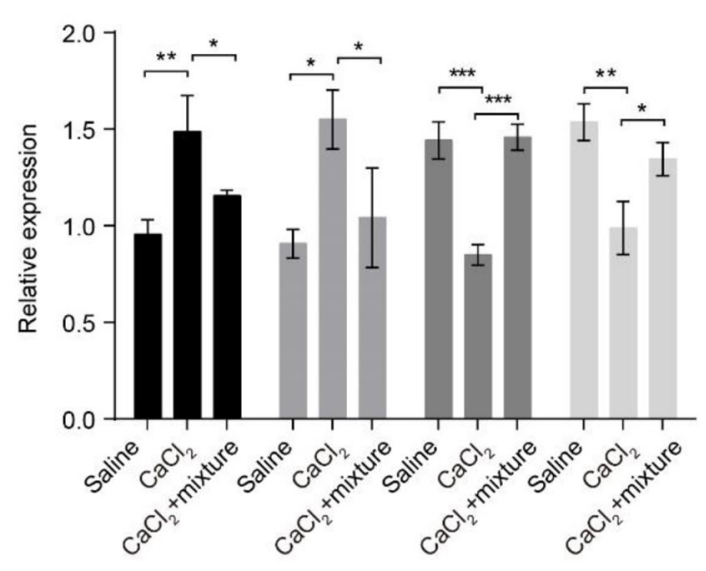

FIGURE 8 | The mixture of GS-Re and lysozyme ameliorates abdominal aortic aneurysm (AAA) progression. (A) Representative morphology of aortas in saline or $\mathrm{CaCl}_{2}$-induced mice treated by GS-Re or the mixture of GS-Re and lysozyme. (B) Quantification of maximal aortic diameters in saline or CaCl ${ }_{2}$-induced mice treated by GS-Re or the mixture of GS-Re and lysozyme. (C) Hematoxylin (HE) and Elastic-Van Gieson (EVG) staining of aortas in saline or CaCl 2 -induced mice treated by the mixture of GS-Re and lysozyme. The top bar $=200 \mu \mathrm{m}$, the middle and lower bar $=50 \mu \mathrm{m}$. (D) Immunohistochemistry analysis for the expression of MMP-9, PCNA, $\mathrm{SM}-\alpha$-actin, and SM22 $\alpha$. Bar $=50 \mu \mathrm{m}$. Data are presented as mean $\pm \mathrm{SD},{ }^{\star} P<0.05,{ }^{\star \star} P<0.01,{ }^{\star \star \star} P<0.001$. 
PNS, GS-Re might be the only one that reduced VSMC viability through joint application with lysozyme, and GS-Re might play a synergistic role by combing with lysozyme.

Next, to determine the interaction between GS-Re and lysozyme, mass spectrometry was applied. We found that the binding ability of GS-Re and lysozyme increased with the ratio of GS-Re to lysozyme from $4: 1$ to $12: 1$, and the concentration ratio of GS-Re to lysozyme was 12:1 as the subsequent experimental condition. We also found that the relative contents of $\alpha$ helix in lysozyme of supramolecular complex formed by GS$\mathrm{Re}$ and lysozyme were increased, which is not only beneficial for stabilizing the structure of lysozyme and maintaining the exposure of Glu35 and Asp52 active sites to keep the specific biological activity of lysozyme, but also possible to bring the GS-Re-lysozyme complex closer to the surface of the cell membrane to perform synergistic functions. Then, based on the concentration ratio of GS-Re to lysozyme of 12:1, in dose-response studies, we revealed that the mixture of GS-Re and lysozyme did not significantly decrease PDGF-BB-induced viability of VSMCs until they reached $12.8 \mu \mathrm{mol} / \mathrm{L}$ GS-Re+1.067 $\mu \mathrm{mol} / \mathrm{L}$ lysozyme, whereas $12.8 \mu \mathrm{mol} / \mathrm{L}$ GS-Re or $1.067 \mu \mathrm{mol} / \mathrm{L}$ lysozyme used along had no effect on VSMC viability.

At the molecular level, we continued to replicate the VSMC phenotype transformation model with PDGF-BB in vitro, exhibiting downregulation of differentiated markers (such as SM- $\alpha$-actin and SM22 $\alpha$ ) and upregulation of dedifferentiated markers (such as MMP-9 and PCNA), consistent with our and other's previous studies (1, 36-39). The results from qRT-PCR and Western blot demonstrated that the 12:1 mixture of GS-Re and lysozyme $(12.8 \mu \mathrm{mol} / \mathrm{L}$ GS-Re+1.067 $\mu \mathrm{mol} / \mathrm{L}$ lysozyme) reversed the downregulation of differentiated markers and upregulation of dedifferentiated markers. Our current study also provided evidence that PDGF-BB-induced VSMC migration activity was markedly reduced by the 12:1 mixture in vitro.

In addition, many studies have highlighted that VSMC phenotypic transition may be an essential prerequisite for aortic aneurysms formation (22). Therefore, $\mathrm{CaCl}_{2}$-induced AAA model was used to test the effect of the mixture of GS-Re and lysozyme. The current study documented that the mixture diminished the development of AAA and presented with the decreased elastin degradation and maintaining the differentiated phenotype of VSMCs in media, implying the obviously synergistic role of GS-Re and lysozyme in vivo.

\section{REFERENCES}

1. Gomez D, Owens GK. Smooth muscle cell phenotypic switching in atherosclerosis. Cardiovasc Res. (2012) 95:156-64. doi: 10.1093/cvr/cvs115

2. Bennett MR, Sinha S, Owens GK. Vascular smooth muscle cells in atherosclerosis. Circ Res. (2016) 118:692702. doi: 10.1161/CIRCRESAHA.115.306361

3. Doran AC, Meller N, McNamara CA. Role of smooth muscle cells in the initiation and early progression of atherosclerosis. Arterioscler Thromb Vasc Biol. (2008) 28:812-9. doi: 10.1161/ATVBAHA.107.159327

\section{CONCLUSION}

In summary, the current study identifies the critical role of lysozyme in PNS preventing phenotypic transformation of VSMCs. These findings reveal a mechanism that a small amount of lysozyme significantly promotes the efficacy of PNS by interacting with Gs-Re both in vitro and in vivo. The finding broadens our understanding of how GS-Re and lysozyme interact with each other, and eventually achieves synergistic effects, which may shed light on the therapeutic strategy for vascular remodeling diseases.

\section{DATA AVAILABILITY STATEMENT}

The raw data supporting the conclusions of this article will be made available by the authors, without undue reservation.

\section{ETHICS STATEMENT}

The animal study was reviewed and approved by Hebei Medical University.

\section{AUTHOR CONTRIBUTIONS}

PL and YZ conducted experiments and wrote the manuscript. YH and LC did Spectral analysis. LC, HY, NC, and HG planned and did in vitro experiments, including cell culture, Western blot, cell viability assay, qRT-PCR, and cell migration assay. YH, XG, RW, WS, and YW planned and did in vivo experiments, including AAA model, HE, EVG, and IHC staining. All authors contributed to the article and approved the submitted version.

\section{FUNDING}

This work was supported by the National Key Research Project of China (2019YFC1606400), Major Public Welfare Projects in Henan Province (201300110200), National Key Research Project of Hebei Province (20375502D), Natural Science Foundation of Hebei Province (H2019206212, H2021206427), High-level Talent Funding Project of Hebei Province (A201905006), Fund of National R\&D Center for Edible Fungus Processing Technology, Henan University (20200109), the Open Fund from Beijing Advanced Innovation Center for Food Nutrition and Human Health (20182025), and Science and Technology Project of Hebei Education Department (QN2018058).
4. Ailawadi G, Moehle CW, Pei H, Walton SP, Yang Z, Kron IL, et al. Smooth muscle phenotypic modulation is an early event in aortic aneurysms. J Thorac Cardiovasc Surg. (2009) 138:1392-9. doi: 10.1016/j.jtcvs.2009.07.075

5. Wu L, Zhang W, Tang YH, Li H, Chen BY, Zhang GM, et al. Effect of total saponins of "panax notoginseng root" on aortic intimal hyperplasia and the expressions of cell cycle protein and extracellular matrix in rats. Phytomedicine. (2010) 17:233-40. doi: 10.1016/j.phymed.2009.07.021

6. Yang F, Ma Q, Matsabisa MG, Chabalala H, Braga FC, Tang M. Panax notoginseng for cerebral ischemia: a systematic review. Am J Chin Med. (2020) 48:1331-51. doi: 10.1142/S0192415X20500652 
7. Xu D, Huang P, Yu Z, Xing DH, Ouyang S, Xing G. Efficacy and safety of panax notoginseng saponin therapy for acute intracerebral hemorrhage, metaanalysis, and mini review of potential mechanisms of action. Front Neurol. (2014) 5:274. doi: 10.3389/fneur.2014.00274

8. Yang $\mathrm{X}$, Xiong $\mathrm{X}$, Wang $\mathrm{H}$, Wang J. Protective effects of panax notoginseng saponins on cardiovascular diseases: a comprehensive overview of experimental studies. Evid Based Complement Alternat Med. (2014) 2014:204840. doi: 10.1155/2014/204840

9. Nakimbugwe D, Masschalck B, Deckers D, Callewaert L, Aertsen A, Michiels CW. Cell wall substrate specificity of six different lysozymes and lysozyme inhibitory activity of bacterial extracts. FEMS Microbiol Lett. (2006) 259:416. doi: 10.1111/j.1574-6968.2006.00240.x

10. Chung J, Ku SK, Lee S, Bae JS. Suppressive effects of lysozyme on polyphosphate-mediated vascular inflammatory responses. Biochem Biophys Res Commun. (2016) 474:715-21. doi: 10.1016/j.bbrc.2016.05.016

11. Abdou AM, Higashiguchi S, Aboueleinin AM, Kim M, Ibrahim HR. Antimicrobial peptides derived from hen egg lysozyme with inhibitory effect against Bacillus species. Food Control. (2007) 18:173-8. doi: 10.1016/j.foodcont.2005.09.010

12. Wu TT, Jiang QQ, Wu D, Hu YQ, Chen SG, Ding T, et al. What is new in lysozyme research and its application in food industry? Rev Food Chem. (2019) 274:698-709. doi: 10.1016/j.foodchem.2018.09.017

13. Ben Amara C, Degraeve P, Oulahal N, Gharsallaoui A. pH-dependent complexation of lysozyme with low methoxyl (LM) pectin. Food Chem. (2017) 236:127-33. doi: 10.1016/j.foodchem.2017.03.124

14. Du YG, Du Y, Cui M, Liu ZQ. Characterization of the noncovalent interactions between Lysozyme and Panaxadiol Glycosides by Intensity-Fading-MatrixAssisted Laser Desorption Ionization - Mass Spectrometry (IF-MALDI-MS). Anal Lett. (2021) 54:2387-94. doi: 10.1080/00032719.2020.1867995

15. Wu Y, Cui LJ, Qu LL, Wang R, Chen N, Huang Y, Zhang Y, Lv P. The effect of luteolin and luteoloside on the secondary structure of lysozyme. J Food Quality. (2021). doi: 10.1155/2021/5523965

16. Qu CL, Yu SC, Bai AX, Wang JS. Study on the interactions between ginsenosides and lysozyme under acidic condition by ESI-MS and molecular docking. Spectrochim Acta A. (2011) 78:676-80. doi: 10.1016/j.saa.2010.11.047

17. Huang Y, Cui LJ, Wang JM, Huo K, Chen C, Zhan WH, et al. Comparative studies on interactions of baicalein, baicalin and scutellarin with lysozyme. Eur J Med Chem. (2011) 46:6039-45. doi: 10.1016/j.ejmech.2011.10.016

18. Yang H, Li J, Cui L, Ren Y, Niu L, Wang X, et al. Synergistic cytotoxicity and mechanism of caffeine and lysozyme on hepatoma cell line HepG2. Spectrochim Acta A Mol Biomol Spectrosc. (2018) 193:16974. doi: 10.1016/j.saa.2017.12.020

19. Zhang W, Chen G, Deng CQ. Effects and mechanisms of total Panax notoginseng saponins on proliferation of vascular smooth muscle cells with plasma pharmacology method. J Pharm Pharmacol. (2012) 64:13945. doi: 10.1111/j.2042-7158.2011.01379.x

20. Lv P, Zhang F, Yin YJ, Wang YC, Gao M, Xie XL, Zhao LL, Dong LH, Lin YL, Shu YN et al. SM22alpha inhibits lamellipodium formation and migration via Ras-Arp2/3 signaling in synthetic VSMCs. Am J Physiol Cell Physiol. (2016) 311:C758-67. doi: 10.1152/ajpcell.00033.2016

21. Sheng L, Wang J, Huang M, Xu Q, Ma M. The changes of secondary structures and properties of lysozyme along with the egg storage. Int J Biol Macromol. (2016) 92:600-6. doi: 10.1016/j.ijbiomac.2016.07.068

22. Zhao G, Fu Y, Cai Z, Yu F, Gong Z, Dai R, et al. Unspliced XBP1 confers VSMC homeostasis and prevents aortic aneurysm formation via FoxO4 interaction. Circ Res. (2017) 121:1331-45. doi: 10.1161/CIRCRESAHA.117. 311450

23. Wang Y, Krishna S, Golledge J. The calcium chloride-induced rodent model of abdominal aortic aneurysm. Atherosclerosis. (2013) 226:2939. doi: 10.1016/j.atherosclerosis.2012.09.010

24. Lu WW, Jia LX, Ni XQ, Zhao L, Chang JR, Zhang JS, Hou YL, Zhu Y, Guan YF, Yu YR, et al. Intermedin1-53 attenuates abdominal aortic aneurysm by inhibiting oxidative stress. Arterioscler Thromb Vasc Biol. (2016) 36:217690. doi: 10.1161/ATVBAHA.116.307825

25. Gerthoffer WT. Mechanisms of vascular smooth muscle cell migration. Circ Res. (2007) 100:607-21. doi: 10.1161/01.RES.0000258492.96097.47

26. Du YY, Wang Y, Wang L, Liu B, Tian QY, Liu CJ, Zhang T, Xu QB, Zhu Y, Oldberg A, et al. Cartilage oligomeric matrix protein inhibits vascular smooth muscle calcification by interacting with bone morphogenetic protein-2. Circ Res. (2011) 108:917-U979. doi: 10.1161/CIRCRESAHA.110.234328

27. Mao C, Ma Z, Jia Y, Li W, Xie N, Zhao G, Ma B, Yu F, Sun J, Zhou $Y$, et al. Nidogen-2 maintains the contractile phenotype of vascular smooth muscle cells and prevents neointima formation via bridging Jagged1-Notch3 signaling. Circulation. (2021) 144. doi: 10.1161/CIRCULATIONAHA.120.053361

28. Salmon M, Gomez D, Greene E, Shankman L, Owens GK. Cooperative binding of KLF4, pELK-1, and HDAC2 to a G/C repressor element in the SM22alpha promoter mediates transcriptional silencing during SMC phenotypic switching in vivo. Circ Res. (2012) 111:685-96. doi: 10.1161/CIRCRESAHA.112.269811

29. Lv P, Miao SB, Shu YN, Dong LH, Liu G, Xie XL, et al. (2012) Phosphorylation of smooth muscle 22alpha facilitates angiotensin II-induced ROS production via activation of the PKCdelta-P47phox axis through release of PKCdelta and actin dynamics and is associated with hypertrophy and hyperplasia of vascular smooth muscle cells in vitro and in vivo. Circ Res. 111:697707. doi: 10.1161/CIRCRESAHA.112.272013

30. Shen J, Yang $M$, Ju $D$, Jiang $H$, Zheng JP, $X u \quad Z$, et al. Disruption of SM22 promotes inflammation after artery injury via nuclear factor kappaB activation. Circ Res. (2010) 106:135162. doi: 10.1161/CIRCRESAHA.109.213900

31. Lv $\mathrm{P}$, Yin YJ, Kong $\mathrm{P}$, Cao L, Xi H, Wang $\mathrm{N}$, et al. SM22a loss contributes to apoptosis of vascular smooth muscle cells via macrophage-derived circRasGEF1B. Oxid Med Cell Longev. (2021) 5564884. doi: 10.1155/2021/5564884

32. Yan Z, Am A, Hao XB, Ning CB, Rong WB, Cy B, et al. Antrodia cinnamomea ameliorates neointimal formation by inhibiting inflammatory cell infiltration through downregulation of adhesion molecule expression in vitro and in vivo. Food Sci Human Wellness. (2021) 10:421-30. doi: 10.1016/j.fshw.2021.04.004

33. Bijelic A, Molitor C, Mauracher SG, Al-Oweini R, Kortz U, Rompel A. Hen egg-white lysozyme crystallisation: protein stacking and structure stability enhanced by a tellurium(VI)-centred polyoxotungstate. Chembiochem. (2015) 16:233-41. doi: 10.1002/cbic.201402597

34. Sun T, Wang P, Deng T, Tao X, Li B, Xu Y. Effect of panax notoginseng saponins on focal cerebral ischemia-reperfusion in rat models: a metaanalysis. Front Pharmacol. (2020) 11:572304. doi: 10.3389/fphar.2020.572304

35. Zhang J, Guo F, Zhou R, Xiang C, Zhang Y, Gao J, et al. Proteomics and transcriptome reveal the key transcription factors mediating the protection of Panax notoginseng saponins (PNS) against cerebral ischemia/reperfusion injury. Phytomedicine. (2021) 92:153613. doi: 10.1016/j.phymed.2021.153613

36. Dong LH, Li L, Song Y, Duan ZL, Sun SG, Lin YL, et al. TRAF6-Mediated SM22alpha K21 ubiquitination promotes G6PD activation and NADPH production, contributing to GSH homeostasis and VSMC survival in vitro and in vivo. Circ Res. (2015) 117:684-94. doi: 10.1161/CIRCRESAHA.115.306233

37. Dong LH, Lv P, Han M. Roles of SM22alpha in cellular plasticity and vascular diseases. Cardiovasc Hematol Disord Drug Targets. (2012) 12:11925. doi: 10.2174/1871529X11202020119

38. Dong LH, Wen JK, Liu G, McNutt MA, Miao SB, Gao R, et al. Blockade of the Ras-extracellular signal-regulated kinase $1 / 2$ pathway is involved in smooth muscle 22 alpha-mediated suppression of vascular smooth muscle cell proliferation and neointima hyperplasia. Arterioscler Thromb Vasc Biol. (2010) 30:683-91. doi: 10.1161/ATVBAHA.109.200501

39. Alexander MR, Owens GK. Epigenetic control of smooth muscle cell differentiation and phenotypic switching in vascular development and disease. Аnnu Rev Physiol. (2012) 74:13-40. doi: 10.1146/annurev-physiol-012110-142315

Conflict of Interest: The authors declare that the research was conducted in the absence of any commercial or financial relationships that could be construed as a potential conflict of interest.

Publisher's Note: All claims expressed in this article are solely those of the authors and do not necessarily represent those of their affiliated organizations, or those of the publisher, the editors and the reviewers. Any product that may be evaluated in this article, or claim that may be made by its manufacturer, is not guaranteed or endorsed by the publisher. 
Copyright (c) 2021 Huang, Cui, Yang, Chen, Guo, Gan, Wang, Shi, Wu, Zhang and Lv. This is an open-access article distributed under the terms of the Creative Commons Attribution License (CC BY). The use, distribution or reproduction in other forums is permitted, provided the original author(s) and the copyright owner(s) are credited and that the original publication in this journal is cited, in accordance with accepted academic practice. No use, distribution or reproduction is permitted which does not comply with these terms. 